\title{
FROM TEXT TO ANIMATION: ADAPTATION OF BAWANG PUTIH BAWANG MERAH
}

Tengku Intan Marlina Tengku Mohd Ali

inmarlin@um.edu.my

Hashim Awang

hashim.awang@um.edu.my

MadiawatiMamat@Mustaffa

atie@um.edu.my

Nur Hamizah Hashim

meza1096@yahoo.com.my

Academy of Malay Studies,

University of Malaya,

50603 Kuala Lumpur, MALAYSIA.

Tel: +603-89216496.

\begin{abstract}
The adaptation of literary texts into drama, film and animation is increasingly popular in today's era of advances in science and technology. Bawang Putih Bawang Merah (Garlic and Shallot) is one of the works which has been adapted into the form of film and animation. One of the animations adapted from text to film that received overwhelming response from the audience in 2001 was Putih directed by Rashid Sibir, produced by Fine Animation Sdn. Bhd. In animation, several changes are made, including changes to the title, characters and characters, setting and events to suit the target audience, and the times. In relation to this, the objective of this article is to analyse the adaptation from different Bawang Putih Bawang Merah texts into the animated form to ascertain the modifications made when certain works are converted into animation, and to investigate how far literary values are adapted into
\end{abstract}


TENGKU INTAN MARLINA, HASHIM AWANG, MADIAWATI, NUR HAMIZAH,

multimedia forms. This study will use the work of Rubaidin Siwar published by Dewan Bahasa dan Pustaka (1990) because it is a more complete text as compared to others. In discussing adaptations, Engelstad (2009) explains how there are four stages involved in the process of adaptation, the first being the narrative, the second the transformation of the verbal to visual, with the third stage being "enunciation", and the fourth being the comprehensive stage. All four stages are applied in the analysis of $B P B M$ in its adaptation from text to animation. The adaptation process involved in converting the $B P B M$ texts into the multimedia form retains the literary elements through the use of various story-telling techniques, to produce a captivating animated film. Although $B P B M$ is a traditional Malay tale, the story is adapted with various interesting elements befitting the needs of today's generation.

Keywords: animation, Bawang Putih Bawang Merah, adaptation, text, multimedia

\section{INTRODUCTION}

Bawang Putih Bawang Merah (BPBM) is a folk tale from Malaysia as well as Indonesia. It was first spread in the oral tradition, then compiled in books and made into various film versions and most recently presented in the form of animation. The changes in its form of presentation and story-telling as various versions exhibits the many interesting elements in $B P B M$, so much so that this story is presented in myriad forms, whether orally, textually or through multimedia elements.

$B P B M$ was produced in the form of texts in many versions, among which were Bawang Merah and Bawang Putih by Khadijah Hashim published by Institut Terjemahan Negara Malaysia (The Malaysian National Institute of Translation) (ITNM) in 2009. This work has been translated into English (30 pages). Prior to this, ITNM had also translated the book Bawang Putih Bawang Merah by Othman Putih into Tamil in 2007 (21 pages). Bawang Putih Bawang Merah by Sulaiman Zakaria was published by Pustaka Printis in 1995 (29 pages), and earlier than this, there was Bawang Putih Bawang Merah by Rejab F.I., published by Tempo Publishing in 1993 (40 pages). However, this study will refer to the work by Rubaidin Siwar published by Dewan Bahasa dan Pustaka in 1990 because this text is more complete than others. $B P B M$ in the other texts mentioned is too brief and simple because these texts seem to be meant for children's reading.

In line with modernization and technological advances today, $B P B M$ has also been adapted into film and animation. Early on, $B P B M$ was made into 
a film in 1959, directed by S. Roomai Noor, produced by Cathay-Kris Film. This film was later also adapted into animated form in 2001 with the title Putih, directed by Rashid Sibir, and produced by Fine Animation Sdn. Bhd. In brief, $B P B M$ is the story of the family of Pak Ali who has two wives, Labu and Kundur. These marriages produce two daughters, Bawang Merah and Bawang Putih. After the demise of Pak Ali, Labu and Kundur constantly argue due to feelings of envy and dissatisfaction towards each other. Many conflicts arise which cause them to become poorer and poorer. Bawang Merah is a beautiful and kind young woman who is constantly physically and mentally abused by her stepmother and stepsister, especially after the demise of her biological mother. Bawang Merah's hardship ends with joy and happiness after she is married to a prince.

What can be seen from all three versions of $B P B M$ is that several changes have been made, including modifications in to the title, characters and characterization, setting and events to suit the target audience and the times. In relation to that, this article will focus on investigating adaptations of $B P B M$ from text to animated form to study the changes which take place when a work is converted into animated form, while investigating how much of its literary value is maintained in the multimedia form.

Menerusi penggunaan animasi, sesuatu mesej atau pengetahuan dapat disampaikan dengan lebih mudah dan berkesan. Oleh yang demikian, sewajarnya teknologi ini diterokai dengan lebih mendalam agar kelebihannya dapat dimanfaatkan secara optimum.

(Through the use of animation, a message or information can be delivered more easily and effectively. As such, this technology should be explored deeper and accordingly to ensure its advantages can be fully optimised.)

(Jamalludin, 2006:iii)

In its literal sense, the term "animation" refers to something having movement or life. Generally, to animate an object has the meaning of making an object move to make it come to life. Animation became widely known and popular through television that showed moving pictures, recorded products, events, live recording encompassing human, animals or plants (Anung, 2010). Animation is one of many multimedia elements to deliver information interactively. The term "animation" is derived from the English root word "to animate", which is to give life. A general definition of animation is that it gives life, making lifeless objects move; a lifeless thing is given strength, 
TENGKU INTAN MARLINA, HASHIM AWANG, MADIAWATI, NUR HAMIZAH, spirit and emotion to come to life and move, or simply to affect life (http:// atan69.files.wordpress.com/2009/09/minggu-1-pengenalan-animasi12.pdf, 2012).

Jamalludin Harun (2005), explains that animation is derived from the Latin word that means "bring to life". According to Kamus Dewan, a dictionary published by Dewan Bahasa dan Pustaka, animation refers to "an action or a process of making something appear to be alive." The Computer Animation Dictionary (http://oxforddictionaries.com/definition/english/ animation, 2012), on the other hand, defines animation as a process that shapes an illusion of movement in film or video through the composition of photographs, or even the combination of movements which are recorded from a framework of images. Each frame or framework of images contains some variations in them and when presented in a time frame at full speed, will form an illusion of movement.

$B P B M$ in animated form is a striking innovation in the field of Malay literature today. An animated work such as Putih appeals to people and attracts them to works of literature due to being more interactive and interesting nature, aside from providing entertainment and moral lessons to the public.

The animated version of Putih offers something different and has revolutionized the Malaysian film industry whereby folklore is presented in comic form, capable of providing entertainment and moral lessons to the Malaysian film audience. Akmal Abdullah (2001) states:

Tidak keterlaluan saya menyifatkan kehadiran "Putih" sebagai perkembangan menggembirakan untuk industri animasi negara kerana produk kartun bergerak begitu rumit untuk berkembang berbanding filem cereka atau drama.

(I will not be exaggerating to describe the presence of "Putih" as a delightful development for the nation's animation industry because the product of moving cartoons is rather complicated to develop, compared to short films or drama.)

(AkmalAbdulllah,2001,http://www.sinemamalaysia.com.my/ main/clippingnews/Filem_Putih_tampil_isi_kekosongan_2073)

As such, the adaptation of literary works into animated form has a big impact on the development of the world of literature today. Nevertheless, the adaptation of a literary work must meet literary criteria to ensure that maximum benefit can be gained from the work. 


\section{APPROACHES TO ADAPTATION}

Adaptation is the conversion of a certain work into another type of work, whether duplicated fully from the original, or altered, and with additions or omissions. The process of adapting one work into another brings about many advantages which are in line with today's technological advancement. Adaptations can be in various mediums, whether in print or online, whichever that enables literary works to be enjoyed by the world at large.

According to Kate Atkinson (2002), adaptation is defined as "all matter transformed into other matter", which is the transformation from one medium into another medium. Genette (1997) on the other hand, relates adaptation to the study of hypertextuality, "the act of writing a text, in whatever genre, with other texts in mind as a "transgeneric practice".

Adaptation is further explained by Alan Rosenthal in Julie Sanders (2006), that is, adaptation is a process that transforms, corrects, shapes and simplifies. In fact, according to him, this editing and creating (of a new product) is an art, and the true technical aspect of the adaptation process. He also suggests two main approaches in the process of adaptation which are, firstly, staying true to the original work and, secondly, creating something totally new. According to him, an adaptation that is true to the original work is not very good, while the second approach, in which something new is created, is better. However, the new product must be true to the spirit and emotion of the original work even though the work is now channelled through a different medium or technique.

Adaptation is not something new. This is explained by Booker (2004 in Engelstad, 2009), that is, adaptation is not a new phenomenon, since, in the past, works were also adapted from other works.

Adaptation is not a new phenomenon at all. Intertextual studies show that stories always seem to derive from other stories. Even the ancient Greek playwrights, like Sophocles and Euripides, based their plays in most cases on myths and stories that had already been told. The British scholar Christopher Booker recently published a very thorough piece of research in which he showed, and in fact proved, that most stories of the world - from myths and fairy-tales, novels and plays to Hollywood films and TV soap operas can structurally and thematically be reduced to "seven basic plots" - which is also the title of his study.

(Engelstad,2009.http://www.caen.iufm.fr/colloque_iartem/pdf/engelstad.pdf) 
In discussing adaptation, Engelstad (2009) explains that there are several processes involved in adaptation, which are the narrative stage, the verbal to visual stage, the enunciation stage and the comprehensive stage. These four stages are applied in the analysis of $B P B M$ and its adaptation from text to animation in this article. These four stages must be investigated together in order to show the processes involved in changing text into animation. These stages will be explained in the analysis.

Sohaimi Abdul Aziz (2011), talks about the adaptation of the novel Lasykar Pelangi (2005) into the film Lasykar Pelangi (2008) using the approach proposed by Engelstad (2009). His article as published in Jurnal Kemanusiaan (2011) discusses the four stages of adaptation from novel to film to view two differing works that are yet inter-related. Nonetheless, Sohaimi Abdul Aziz's article varies from this article. Even though this study also investigates adaptation using the same approach, it gives more focus to adaptation into animation, in this case, the adaptation of $B P B M$ from text to animation.

\section{ADAPTATION OF BPBM INTO PUTIH}

The study of BPBM into the adapted animated version, Putih, is described below to explain the transformation from text into multimedia, through the four stages as proposed by Engelstad (2009) that explain the aspects of retaining, editing or omitting in a story.

\section{Narrative Stage}

The narrative stage is the stage at which the literary text is compared to the script of the multimedia animated version. For analysis at this stage, several matters are looked into such as "What has been kept of the novel's narrative? What has been reduced - and why? What has been changed from novel to film narrative? What has been added? (Engelstad, 2009. http://www.caen. iufm.fr/colloque iartem/pdf/engelstad.pdf).

Matters such as aspects of retention, editing and omission should be discussed in the adaptation of a work, whether the adaptation is from text to film or even from text into animation. Although the theory explains the transformation from text to film, the approach can also be used in studies on adaptations from text to animation. Animation and film are not very different because both forms highlight, among others, the combination of audio and visual aspects to make the work more interesting and appealing to the public. 
The most striking difference is only in the characters' appearance. If film shows realistic characters, animation features cartoon characters to create interesting animation effects.

Kehadiran animasi dalam sesuatu persembahan dapat menceriakan keadaan penyampaian, sesuatu konsep yang kompleks, juga dapat dipersembahkan dengan lebih mudah dan ringkas.

(The presence of animation in a show can enliven the delivery, a complex concept can also be presented more easily and simply.)

(Jamalludin dan Zaidatun, 2005:4)

In relation to that, the animated film, Putih, is presented using more interactive and interesting new media to attract the public to scrutinize traditional works of literature which are rich in educational elements. The elements found in this traditional work of literature are still applicable to the life of today's society. Therefore, this paper investigates the aspects of adaptation from text to animation to explain the changes that take place when a work is converted into animated form, and studies the extent to which literary values suit adaptation into a multimedia form. At the narrative stage, the aspects which will be explained encompass aspects of retention, addition and omission.

\section{(a) Retention}

Here, the similar elements present in the transformation of the text of $B P B M$ into its multimedia form, Putih, are studied. It is found that there is very little transfer of the original text BPBM to the animated form (Putih). The only element is that of the plot or storyline.

This is in line with the view of Sohaimi Abdul Aziz (2011:39) who explains that in the process of adapting novels into films, there are directors or scriptwriters who remain true to the original work, and there are those who do not. When a director or creator is not true to the text, he will do three things: retaining, editing and omitting from the original work. These three things are related to several factors such as the different media involved, commercial significance, the agenda of the writer, producer or film studio, as well as artistic importance and the like.

In relation to this, few aspects seem to have been retained in the adaptation of $B P B M$ into the animated version, Putih. The clearest aspect of retention 
TENGKU INTAN MARLINA, HASHIM AWANG, MADIAWATI, NUR HAMIZAH,

aspect in both is that of the life of Mak Labu and Mak Kundur after the demise of their husband. Various conflicts arise due to the greed, envy and dissatisfaction of Mak Labu towards her co-wife and stepdaughter. Due to this, many things occur that bring about hardship and injustice towards Mak Kundur and her daughter. These conflicts help to develop the plot in an interesting way and arouse the audience's curiosity.

$B P B M$ is a timeless tale, as the issues presented in it still occur to this very day. Among them are human attitudes such as envy, greed, treachery and dissatisfaction, which are still relevant to today's society. This story was very effective in its time, teaching that greed and envy lead to self-destruction, while patience and acts of kindness lead to happiness in the end.

In the animated version, Putih, the conflicts that occur in the family are presented in a very interesting manner through the way the characters are drawn. The characters in this cartoon become more interesting because they are given facial expressions and using suitable audio effects. Examples from Figure 1 depict the conflicts in both versions. In picture (i), the character Mak Kundur is shows to be constantly annoyed with her co-wife and stepdaughter. What is interesting is that through animation, the facial expression can be directly seen, unlike in the text, whereby the emotions of the character are expressed through a certain narrative technique. In example (ii), on the other hand, Mak Kundur is portrayed as always gloomy and sad because she is always bullied by Mak Labu. Examples (iii) and (iv) show the images that provide an explanation of the conflicts in the family. Picture (iii) portrays the image of Mak Kundur scolding Bawang Putih because Putih is said to be a lazy person who refuses to do household chores. Mak Kundur's fierce look with a scolding facial expression can be seen in the pictures. The same applies to Bawang Merah, whose facial expression clearly gives out her satisfaction and joy at Bawang Putih being scolded by her mother. Picture (iv) shows Mak Kundur carrying a basket of dirty laundry to have them washed by the river while she is being observed by Mak Labu and Bawang Merah. Mak Kundur walks with a sad face, while Mak Labu has a fierce facial expression because she is monitoring the chores that must be done by Mak Kundur. Bawang Merah on the other hand is shown with her usual affected, arrogant expression as she, too, despises Mak Kundur.

The conflicts explained above were transferred entirely from the $B P B M$ texts. The main theme of the tale, which is about family conflicts, is retained in the animated form using suitable images and sound effects. Jamalludin Harun and Zaidatun Tasir (2005:76) explain that the characters 
(i)

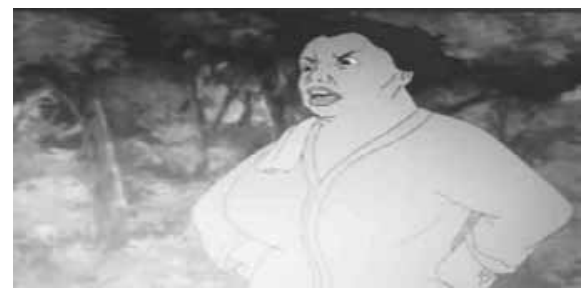

(iii)

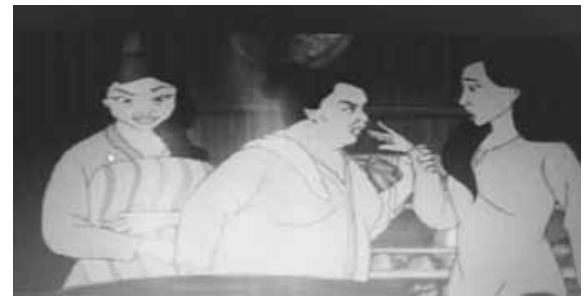

Figure 1 Adaptation of conflicts. (ii)

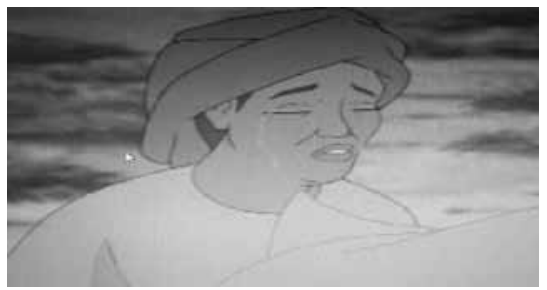

(iv)

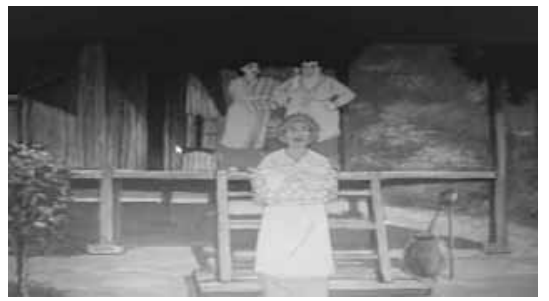

Source: Fine Animation Sdn. Bhd.

which are created and developed must be developed. Facial expressions, sitting positions, standing, walking and others must be identified and fixed. This allows the characters created to possess their own personality, in turn touching the hearts of the audience.

Another aspect of retention that can be identified here is the setting, such as the village, river and palace, which are retained in the animated form. The difference is that in the animation, the village setting is depicted to the minutest detail, that is, the depiction includes social situations such as the market place, interaction among the villagers, and the rural farming system. These are not expressed clearly in the texts. Based on examples in Figure 2, the place setting remains the way they are described in the text. However, the images depicted become more interesting with an explanation voiced over. Example (i) is an image of a palace which has been sketched interestingly in the animated version. In the text, the palace is described in words but in animation it is portrayed clearly as an image of a marvellous palace. Picture I shows the image of the huge, beautiful palace with its spacious courtyard. Picture (ii) is a depiction of a kampung enhanced with activities such as the kampung folk working together to plant rice in the fields. This aspect is not clearly explained in the text. Therefore, it can be said that there is a slight addition in the retention aspect for the adaptation from text to the animated form so as to provide a more interesting portrayal. 
(i)

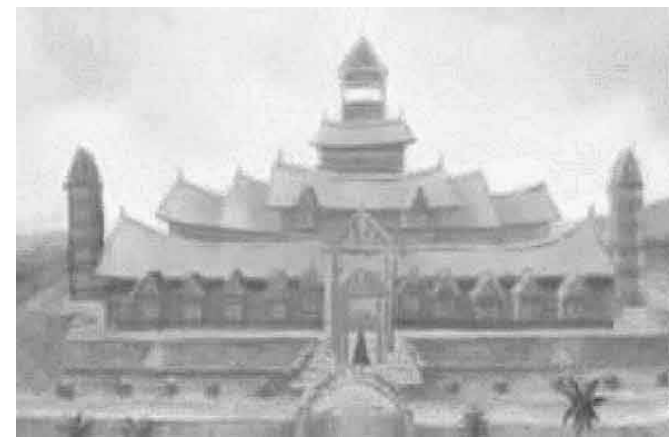

(ii)

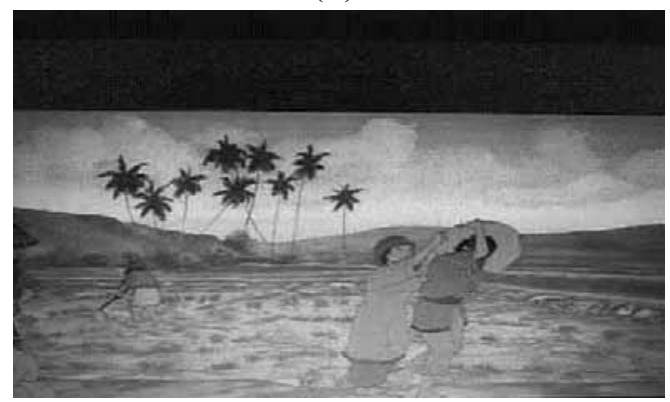

Figure 2 Adaptation of Setting.

Source: Fine Animation Sdn. Bhd.

The plot of $B P B M$ and Putih ending happily is another obvious similarity analysed in this study. Even though in the earlier stage the protagonist (Bawang Merah in BPBM text, Putih in the animation) undergoes various hardship in life, her patience pays off, and in the end she leads a happy life, is married to a prince and lives in the palace for ever and ever.

Generally, not many aspects are retained in their entirety from the written work, however, the major literary aspects such as theme, character and setting remain the same and are modified to suit the form of presentation. What is retained are the elements that may provide moral lessons for people of all times, and that remain relevant even today. Nonetheless, what is apparent in the animated version is that it is more interesting as far as the setting is concerned because it is more detailed. Due to this, the story can be better appreciated by the audience. 


\section{(b) Addition and Alteration}

Adding and altering is a normal practice when any written work is adapted into animated form. Alteration may include changes to the characters, language style, setting or any other aspect to produce an animated work that can present the story in an effective manner. Whatever alterations made depend on the creativity of the editor but are still in accordance with a pre-developed script.

An obvious difference in this story pertains character and characterization, for example, the difference in the names and roles of the characters. In $B P B M$, the protagonist is Bawang Merah, while in Putih, the protagonist character is Putih. Putih is chosen as the main character here because putih (white) is a symbol of purity and suits the protagonist's character as she not only possesses good looks but a good character as well. Furthermore, in terms of nutrition, bawang putih (literally: white onion; the Malay word for garlic) is healthy and nutritious. Putih befits the symbolic nature of this character and is beneficial to the society.

Alterations in the scenes, on the other hand, can be seen in the incident of Pak Ali's demise. In the BPBM story, what is told of Pak Ali's death is that he was stung by a catfish and died, however in Putih, the cause of Pak Sukam's death is not stated. This happens because Putih portrays the conflicts between Putih and her stepmother and stepsister. As such, scenes relating to the life of her father are not depicted in great detail in the animated film. In addition, the animated version is subject to a time limit. As such, the absence of this incident does not affect the plot of the tale.

The scene of Mak Labu's demise is also altered. In Putih, Mak Labu dies after being pushed into the river by Mak Kundur, but in $B P B M$, Mak Labu dies after she is beaten with firewood and bleeds to death before being pushed into the well by Mak Kundur. Mak Kundur's acts of violence and her inhuman nature are apparent in the $B P B M$ texts. In "Putih" animation however, this scene is altered because such violent acts are unsuitable for an audience that comprises children and teens.

The incident where Mak Labu catches a gourami is also found to have been altered. In $B P B M$, it is told that Mak Kundur (who is Bawang Putih's mother in the text) and Bawang Putih catch a gourami (Mak Labu, who has transformed into this fish) after Bawang Merah goes off to work at the plantation. However, in the animated film, Mak Kundur and Merah's strategy to catch the gourami (Putih's mother transformed) is through Mak Kundur pretending to be ill and sending Putih to the kampung across from theirs to get medicine. When Putih leaves for the kampung across the river, Mak 
Kundur and Merah embark on catching the gourami from the river, frying the fish, and serving it to Putih. By modifying this event in Putih animation, the scriptwriter attempts to showcase the element of deceit for a particular purpose. The element of deceit is inserted into the animated work to arouse suspense and curiosity among the audience.

Literary works transformed into animation also undergo modifications aimed to suit the times and logical thinking, to ensure each work that is presented captivates the audience. This study finds that the episode of Prince Aftus who wished to go into battle is meant to bring out the wisdom and intelligence in Putih's character. For example, in the animated Putih, Prince Aftus is deployed to lead an army to the borders of Tanjung Pura kingdom, to defend it against Raja Aria Bupala and his army, for Raja Aria Bupala has already reached the borders of Tanjung Pura. Putih gives suggestions to Prince Aftus on ways to defeat Raja Aria Bupala and his army. One of Putih's strategies is for Raja Aftus to instruct his army to dig trenches in the middle of the battlefield, so that when the soldiers of Raja Aria Bupala walk through the trenches, they will fall into these. In addition to that, Putih requests for Mikus (the rat) and his friends to attack Raja Aria Bupala's soldiers by biting them and eating their food supplies. Upon being bitten by the rats, Raja Aria Bupala's soldiers fall sick. This scene indirectly showcases Putih's wit and intelligence in assisting her husband, Prince Aftus.

Contrary to this, the BPBM text shows Bawang Merah's the naivety and lack of intelligence even as she is queen. For example, Queen Bawang Merah abides to everything asked of her by Mak Kundur. For example, when Mak Kundur asks Queen Bawang Merah to sprinkle the prickly hairs of bamboo onto her husband's sleeping chambers, supposedly to secure her husband's love for her. Additionally, Mak Kundur also convinces Queen Bawang Merah to hang an axe Mak Kundur gives her at the entrance of their bedroom door. When the Raja enters the chambers, the axe hits the Raja's head. This incident incites the Raja's anger towards Queen Bawang Merah, hence he commands Queen Bawang Merah to be executed. However the $B P B M$ story ends with Mak Kundur (mother to Bawang Putih) and Bawang Putih being found guilty of conspiring to set up Queen Bawang Merah. Mak Kundur (mother to Bawang Putih) is punished and exiled by the Raja.

The changes taking place due to the transformation of $B P B M$ into the animated version, Putih, still upholds BPBM's main focus. The reason for the changes are, among others, to suit the context of the era, thus ensuring the work presented can be accepted by the general public. For example, the 
choice of the name Putih matches certain symbolisms which are ingrained in the minds of the Malay community. Furthermore, an animated presentation has its time constraints, hence the need for a brief plot whilst retaining its literary and dramatic effects. The modification of events is so that the story appears more logical and realistic, suitable for all time.

Adding on certain elements in the process of adaptation is aimed at enticing the audience and captivating them. Additions can always be made to the characters, setting, plot and language style. An animated presentation is more interactive and interesting with proper multimedia elements such as graphics, audio, colours and visuals.

With regard to the animated Putih, most of the additions are done to match the story to today's modern society. Significant additions include a delightful melodious syair (sung poem) to depict happy and sad moments. The melody leaves a deep impact on the audience so as to continue following the story. For example, Putih begins with the melodious serenade of a syair that tells the story of the harmonious life of the kampung people. The accompaniment of the melodious syair and the delightful visual display increase the level of understanding, as well as affect the audience's appreciation of the tale in the animated version.

Additions can also be seen in the aspect of characterization. In Putih, animal characters are added, which are a cat and a rat. The cat and the rat here are supporting characters to Putih. The cat is named Gemo while the rat is named Mikus. Both animal characters are highlighted in Putih in order to attract children and to make this plot more interesting. Psychologically, children adore animal characters, especially if they are presented in animated form with interesting cartoon images and are able speak like humans.

Furthermore, in Putih, action-packed elements are added to make the story appear more complex and attractive. This can be seen in the scene where Datuk Bendahara Panglima Bijarana and the character Raja Aria Bupala, who are wolves in sheep's clothing, conspire with the enemy to kill Prince Aftus and conquer Tanjung Pura kingdom.

The same goes for additions in the events of the battle between the two kingdoms in Putih. When Raja Aria Bupala discovers that his plan to kill Prince Aftus is unsuccessful, and that in fact Prince Aftus is said to be going to marry Putih, his hopes of conquering Tanjung Pura kingdom start to fade. Due to this, Raja Aria Bupala gathers and deploys all his soldiers to attack Tanjung Pura kingdom. This is where the action-packed elements take place that fill the story with suspense and tension, consequently attracting the audience to stay with the story. 
An element of slander is also added and inserted into Putih. Putih is defamed and is accused of having an illicit affair and engaging in adultery with Sulong, who is the assistant to Prince Aftus. Mak Kundur is the one who spreads the slander to Raja Aristun. Due to this, Putih is cast out from Tanjung Pura kingdom by Raja Aristun. However, in the end, Raja Aristun discovers that everything was nothing more than slanders by Mak Kundur because of her envy towards Putih. Once Prince Aftus hears the truth of the matter, he leaves Tanjung Pura kingdom in search of Putih and they reunite. Mak Kundur, Bawang Merah, Datuk Bendahara, and Panglima Bijana are punished with a lifetime of servitude at the palace. The addition of the slander element makes the plot in Putih more engaging because it creates the element of suspense and attracts the interest of the audience towards the ending of Putih.

The additions made to Putih, whether in aspects of character, setting, plot and language style set apart "Putih" from the BPBM text. Different audiences will have a different appreciation based on their own understanding and knowledge. Nonetheless, Putih is found to directly affect and captivate children, teens and adults alike due to its effective multimedia elements such as graphics, audio, colours and visuals which are used to optimum effect. Nevertheless, the textual form $B P B M$ has its own uniqueness, such as its ability to improve the power of the audience's imagination with each incident expressed by the writer.

\section{Verbal to Visual Stage}

The adaptation of a literary work into animation is a modification from the verbal to visual form. Literary works in textual form are deemed to be verbal whereas literary works in multimedia form are visual in nature. When a scene is converted into animated form, changes will occur, the scene will either be portrayed in detail using graphics, colours or certain sound effects, or events will be removed entirely, replace by multimedia elements.

The transformation from the verbal into the visual shows in the way the setting is created. For works in textual form, a setting is described by the author through language in various styles, while in animation there is a "real" backdrop that is sketched out, followed by certain sound effects to make the atmosphere more interesting. Also, in an animated work, the audience's imagination is limited as the scenes presented are clear and realistic, with the use of various visuals. On the other hand, literary texts 

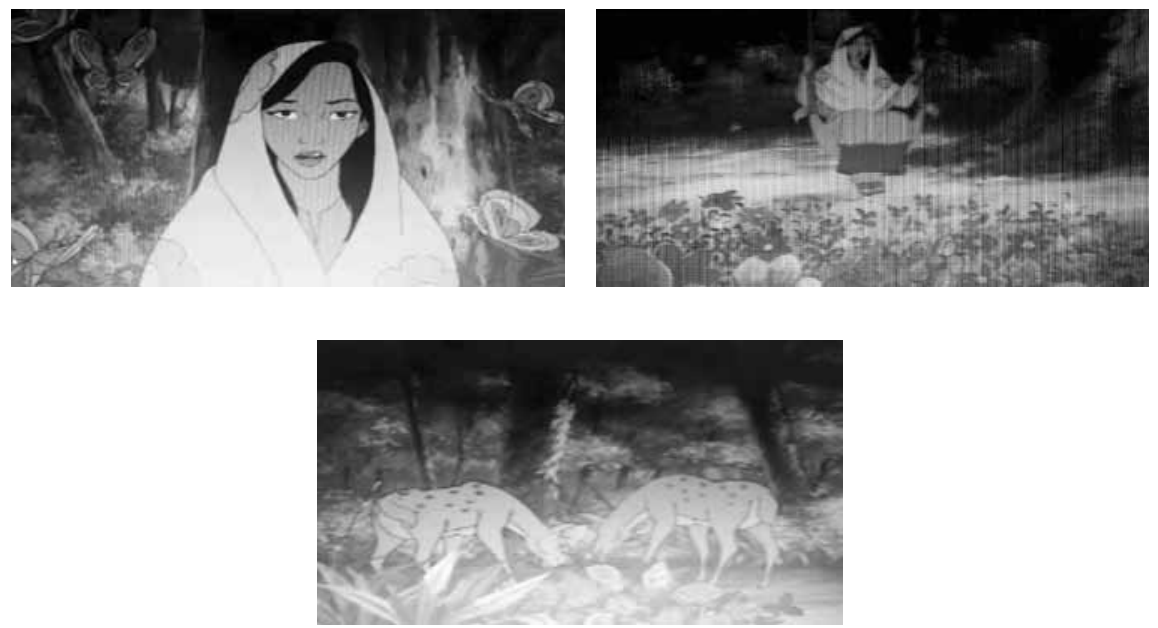

Figure 3 Depiction of Putih sitting on the swing and singing.

Source: Fine Animation Sdn. Bhd.

do not limit the audience's imagination, as the author's language style will excite the minds of the audience to imagine the situation described by the author. The migration from text to visual form can be seen from the example in Figure 3:

Referring to Putih, the scene where the prince and his advisors spy on Putih while she is sitting on the swing and sings, is beautifully depicted, whereby she is seen on a swing under a big tree surrounded by lush greenery, colourful flowers and some deer hunting for food. The description shown in the animation is vivid. The audience no longer needs to imagine what the author attempts to deliver. This is in contrast to the $B P B M$ text that illustrates the scene in this way:

Mereka pun pergi lebih dekat lagi. Dari sebalik pokok besar mereka dapat melihat seorang perempuan muda sedang berbuai-buai di bawah suatu pohon beringin yang amat rendang sambil bergurindam, amat sedih dan sayu bunyinya.

(They went closer. From behind a big tree, they could see a young lady sitting on a swing under a shady banyan tree while singing a tune so sad and melancholic to hear.)

$(B P B M, 1990: 94)$ 
The author's depiction of the scene, using language in the style above, will trigger the audience's imagination of the narrated setting. The scene is not fully converted from text into animation, instead, certain aspects in the animation have been added to enhance the impact of the visual. For example, colourful flowers, green bushes and deer are added.

It is apparent that an animated presentation is more captivating due to its visuals, coupled with suitable sound effects that will bring forth a deeper appreciation towards the story. The colours used can also create all sorts of feelings, whether sadness, gloominess or even joy. In animation, the choice of colours, sizes and graphic structures must correspond to the script provided. Whereas in textual works, language style plays an important role in vividly describing each scene. According to Muhammad Haji Salleh (2000:67), literary language is a meaningful form of speech, for it highlights various significant matters, and has been organized in an effective form.

Apart from that, the aspect of transformation from the verbal to the visual can be seen in the wedding scene between Putih and Raja Aftus. In animation, the joyful atmosphere at the palace is portrayed in a delightful way. The cheerfulness is illustrated in the bersanding (sitting in state) ceremony scene between Putih and Raja Aftus. In the animated film, Putih, Putih and Raja Aftus are seated on a dais wearing complete wedding attire with yellow accessories. Family members and palace chiefs appear to rejoice at the ceremony. There are also a few dance performances during the ceremony. Everything is depicted in a joyous mood. Family, palace chiefs and the people of the kingdom, are all gathered to witness the wedding ceremony. In $B P B M$, the wedding is illustrated as below:

Setelah siap dipakaikan dengan pakaian pengantin kelihatanlah Bawang Merah amat cantik, menjadikan asyik sesiapa yang melihatnya. Upacara akad nikah pun dijalankan kemudiannya, dan setelah itu raja pun disandingkan dengan Bawang Merah di atas pelamin diraja yang dihias indah, disaksikan oleh orang-orang besar negeri serta hamba sekalian. Sekalian yang melihatnya memuji-muji kecantikan kedua pengantin itu, tak ubah seperti pinang dibelah dua.

(After putting on her wedding dress, Bawang Merah looked breathtakingly beautiful and stunned everyone who saw her. The solemnisation ceremony followed, then the Raja was officially married to Bawang Merah in a sittingin-state ceremony, on a beautiful royal dais, witnessed by all the palace chiefs and the people of the kingdom. Those who saw them exclaimed how good-looking both bride and groom were, like two peas in a pod.)

(BPBM, 1990: 110-11) 
There is not much difference between the verbal and the visual versions. Both versions depict the merriness of the wedding ceremony. However, the animated version stands out more and looks more interesting as the festiveness is illustrated using various colours and fascinating songs. Nonetheless, the description given in the text is more detailed, unfolding the process of the royal wedding from beginning to end. For example, there is mention of the wedding attire, solemnization, bersanding ceremony, dais, and wedding guests who are present, as well as a mention of the attractive looks of the bride and groom.

However, there is a scene found in Putih that is an anachronism. For example, on the night of the festivity when the newly-weds enter their bedroom, they watch a fireworks display outside the palace through their bedroom window. The depiction of fireworks is anachronistic for, in reality, fireworks were not yet in existence during the time in which $B P B M$ is set.

The addition of this aspect is merely to showcase the beauty and festive atmosphere of the wedding ceremony. That being said, the festive atmosphere could actually be created through other means which would still relate to the context of the era. For instance, it is told in $B P B M$ that:

Di luar istana suasana riang gembira masih berjalan berhari-hari lamanya. Hamba rakyat bersuka-sukaan dengan mengadakan berbagai pertunjukan dan permainan serta menjamu berbagai jenis hidangan yang disediakan.

(Outside the palace, the festivity continued for many days. The people of the kingdom celebrated with a variety of shows and games, as well as enjoying the many different foods that were prepared.)

$(B P B M, 1990: 111)$

With a description of the atmosphere such as the one above, readers will be able to visualize the festivity of this occasion. Although only words are used without any visual and audio effects, the author's skill in sketching the atmosphere with his words is able to leave a great effect on the reader. Here, it encourages readers to be imaginative as the situation can be interpreted in many ways based on their appreciation of the tale.

That being said, undoubtedly, in the transformation stage from text to animation or from the verbal to the visual, there is bound to be a little modification in terms of the plot, such as in the scene of the wedding ceremony between Putih and Raja Aftus (Putih). In the animation, the joyous celebration at the palace is depicted in a very interesting way, compared to the text of 
TENGKU INTAN MARLINA, HASHIM AWANG, MADIAWATI, NUR HAMIZAH, $B P B M$ which gives only the barest description, leaving readers to have to imagine what takes place during the wedding ceremony.

\section{Enunciation}

Enunciation is an aspect of literary work that cannot be directly converted into animated form. This is where the script writer needs to meticulously plan what and how each aspect of the tale is to be presented so that it will be easily understood and be interesting. Here, elements such as graphics, sound, colours, and music replace the role of language.

Referring to BPBM, the scene where Bawang Merah (Putih in Putih) is grieving is told using explicit detail:

... suaranya yang sedih dan pilu sayup-sayup dibawa angin petang;

"Tinggi-tinggi pohon beringin

Kalau tinggi menyapu awan

Kalau rendah menyapu bumi...

(... Her sad and melancholic voice was carried by the afternoon breeze,

"O towering banyan tree

You scrape the sky when you're high

You sweep the earth when you're low ...)

(BPBM, 1990: 91)

The description of sadness and grief in Putih is not only captured through the song "Kasih Putih" (Putih's Love), sung by the singer, Aishah, but also the atmosphere and movement of images add more depressing effects. For example, the swing Putih sits on moves slowly following the rhythm of the song, the butterflies and birds fly around the area as if they, too, can feel her sorrow. The explicit description in the text is presented through graphics, the rhythm of the song and colours.

In Putih, the relationship between Bawang Putih and Bawang Merah with their father is not relayed at all. The audience learns of their father through the film's flashback scenes, which is in the scene where Mak Labu reminds Mak Kundur about the house Mak Kundur inherits from their late husband:

\footnotetext{
"Kundur, memang betul rumah ini rumah engkau, "

"Ahh tahu pun ..."

"tapi arwah abang Sukam pesan walaupun rumah ini rumah kau, aku dengan Putih mesti tinggal di sini. Macam juga dengan sawah tu, Abang
} 
Sukam bagi sawah dekat aku tapi dia pesan kau anak-beranak boleh makan hasil sawah tu..."

("Kundur, this house is definitely yours, "

"Ahh, you admit it then..."

"But our late husband, Sukam, said that even though this house belongs to you, Putih and I must stay here. Just like the paddy field, Abang Sukam handed it over to me but he reminded me that you and your daughter can also enjoy the crop...")

(Putih, 2001)

Through this argument, the audience indirectly learns about Pak Sukam (Pak Ali in $B P B M$ ). In $B P B M$, the life of Pak Ali and his family is told in great detail throughout the first five chapters. In Putih, however, the story of Pak Sukam (Pak Ali) is only briefly touched in the flashback scenes. This is done in order to shorten the plot of the animation because every production has a specific and limited time and duration.

Where enunciation is concerned, it can be seen that the creator of Putih manages to creatively portray every scene befitting the mood he intends to highlight. The multimedia elements used are able to replace the role of the language of the textual form. The audience is able to empathize with the feelings of the characters. Moreover, the creator's use of the flashback technique is able to shorten the plot.

\section{The Comprehensive Stage}

The final stage, which is the comprehensive stage in an adaptation, is the stage where the story is converted entirely from text into multimedia form. This means that the entire plot of the text is transformed into the adaptation. Studying Putih closely, it can be seen that $B P B M$ is not completely transmuted into animation, as it needs to suit the use of the medium. Modifications are made to all literary aspects such as characters, characterization, plot, setting and narration techniques. Only the theme of the original story is retained and is narrated by the animated work in an interesting way.

BMBP is based on the theme of a child's endurance towards life's hardship and overcoming challenges living with her stepfamily. The main character in both the text and multimedia version is depicted as a strong young woman who perseveres in facing the ridiculous whims and fancies of her wicked stepmother and stepsister. She remains patient and moves 
on with her life despite enduring daily physical abuse and verbal torment. The story has a happy ending when the main character marries a prince and lives happily ever after.

Based on above discussion, it can be stated that Fine Animation Sdn. Bhd retains the overall theme of the tale from text to multimedia form, as the theme is relevant and is a factor that still attracts the audience today. In addition, such a theme is able to bring out the strong points of a story, as from this theme, other subject matters may arise which can make $B P B M$ or Putih more appealing.

\section{CONCLUSION}

Overall, based on the stages of analysis conducted, which consist of four stages in the process of adapting the BPBM text into multimedia form Putihfirstly, the narrative stage, secondly, the verbal to visual stage, thirdly the enunciation stage and the fourthly and finally, the comprehensive stage - this paper has uncovered several findings from the process of adaptation. There are certain aspects which are retained, added and omitted during the adaptation processes. The process of adapting BPBM into multimedia form retains the literary elements of the tale, which is presented through various narration techniques to produce an interesting animation. Though $B P B M$ is a traditional Malay tale, it has been adapted using various interesting elements befitting the needs of today's society. The strength of the literary text $B P B M$ lies the style of its language and its plot which is loaded with conflicts. This story becomes more captivating when adapted into animated form as it contains additions that can bring this piece of folklore to the attention of today's society. In fact, the literary and artistic values present in the story can benefit the audience in terms of art, values and moral lessons. This shows that "Putih" has successfully attracted today's audience to collectively enjoy traditional literature. If efforts such as this are not initiated, our traditional literature will certainly die out and be buried under the current of modernization.

\section{ACKNOWLEDGEMENTS}

We would like to express our appreciation to Fine Art Animation Sdn. Bhd. for their permission to reproduce images from the film Putih in this article. 


\section{REFERENCES}

Ahmad Patria Abdullah, 2012. "Karmawizra: Transformasi Karya Genre Fantasi kepada Siri Animasi". Seminar Antarabangsa Asia Tenggara (SAKAT) VII, 17-18 October 2012. Organized by Dewan Bahasa dan Pustaka, Kuala Lumpur.

Akmal Abdullah, $2001 \mathrm{http} / /$ www.sinemamalaysia.com.my/main/clippingnews/ Filem_Putih_tampil_isi_kekosongan_2073) (17 February 2012).

Anung Rachman, "Studi Penciptaan Multimedia Keris dengan Konsep Animasi Edukasi" in Jurnal Acintya: Jurnal Penelitian Studi Seni Budaya 2:1, pp. 59-68, June, 2010.

Atkinson Kate, 2002. Not the End of the World. London: Doubleday.

Azhar Hj. Wahid (ed.). 2011. Globalisasi Sastera Siber. Tanjong Malim: Universiti Pendidikan Sultan Idris.

Boyle, T., 1997. Design for Multimedia Learning. Europe: Prentice Hall.

Burhan Nurgiyantoro, 1998. Transformasi Unsur Pewayangan dalam Fiksi Indonesia. Jakarta: Gajah Mada Universiti Press.

Computer Animation Dictionary, 2012 http://oxforddictionaries.com/definition/ english/animation (12 January 2012).

Engelstad.A., 2009. Literary Film Adaptations as Educational Texts in http:// www.caen.iufm.fr/colloque_iartem/pdf/engelstad.pdf (12 January 2012).

Genette, Gerard, 1997. Palimpsets: Literature in the Second Degree .Translated by Channa Newman and Claude Doubinsky. Lincoln: University of Nebraska Press.

Jamalludin Harun and Zaidatun Tasir, 2005. Animasi dari Helaian Kertas ke Skrin Digital. Selangor: Venton Publishing (M) Sdn. Bhd.

Khadijah Hashim, 2009. Bawang Merah and Bawang Putih. Kuala Lumpur: Institut Terjemahan Negara Malaysia.

Lamb,C. \& Keller, K., 1997. Multimedia: Animation. Indianapolis: QUE Education \& Training.

Madiawati Mustaffa \& Arbaie Sujud, "Transformasi Medium Tradisi Lisan, Teks dan Bentuk Multimedia dalam Cerita Unggas" in Jurnal Pengajian Melayu, 20, 2009.

Muhammad Haji Salleh, 2000. Puitika Sastera Melayu. Kuala Lumpur: Dewan Bahasa dan Pustaka.

Norhayati Abd. Mukti \& Siew Pei Hwa, "Malaysian Perpective: Designing Interactive Multimedia Learning Environment for Moral Values Education" in Educational Technology \& Society 7:4, pp. 143-52, 2004.

Rejab F.I. , 1993. Bawang Putih Bawang Merah. Kuala Lumpur: Tempo Publishing.

Reeves, T.C., 1992. Evaluating Interactive Multimedia. Educational Technology, 32:5, pp. 47-52.

Robert Stam, 2005. Literature Through Film: Realism, Magic, and the Art of Adaptation. Blackwell Publishing Ltd. 
TENGKU INTAN MARLINA, HASHIM AWANG, MADIAWATI, NUR HAMIZAH,

Rubaidin Siwar, 1990. Bawang Putih Bawang Merah. Kuala Lumpur: Dewan Bahasa dan Pustaka.

Sanders, J., 2006. Adaptation and Appropriation. New York: Routledge Taylor \& Francis Group.

Sulaiman Zakaria, 1995. Bawang Putih Bawang Merah. Kuala Lumpur: Pustaka Rintis.

Sohaimi Abdul Aziz, "Laskar Pelangi: Satu Penelitian Adaptasi Novel Ke Filem" in Jurnal Kemanusiaan.The Asian Journal of Humanities 18:1, pp. 35-52, 2011.

(Translated by Tanja Jonid) 